\title{
Association of dietary intake of milk and dairy products with blood concentrations of insulin-like growth factor 1 (IGF-1) in Bavarian adults
}

\author{
Eugenia Romo Ventura ${ }^{1,2} \cdot$ Stefan Konigorski ${ }^{1,3} \cdot$ Sabine Rohrmann $^{4} \cdot$ Harald Schneider $^{5} \cdot$ Guenter K. Stalla $^{6,7,8}$. \\ Tobias Pischon $^{1,9,10,11}$. Jakob Linseisen ${ }^{12,13} \cdot$ Katharina Nimptsch ${ }^{1}$
}

\begin{abstract}
Purpose Circulating IGF-1 concentrations have been associated with higher cancer risk, particularly prostate, breast and colorectal cancer. There is evidence from observational and intervention studies that milk and dairy products intake is associated with higher IGF-1 concentrations, but results were not always consistent. The purpose of this study was to examine the relationship between dairy intake and circulating IGF-1 concentrations in participants of the Second Bavarian Food Consumption Survey, thereby providing data for a German population for the first time.

Methods In this cross-sectional study of 526 men and women aged 18-80 years, in contrast to most previous investigations, dietary intake was assessed with a more detailed instrument than food frequency questionnaires (FFQs), i.e., by three 24-h dietary recalls conducted on random days close in time to the blood collection. Circulating IGF-1 concentrations were measured in blood samples. Multivariable linear regression models were used to examine the association of dairy intake with IGF-1 concentrations.

Results Each $400 \mathrm{~g}$ increment in daily dairy intake was associated with $16.8 \mu \mathrm{g} / \mathrm{L}$ (95\% CI 6.9, 26.7) higher IGF-1 concentrations. Each $200 \mathrm{~g}$ increment in milk per day was associated with $10.0 \mu \mathrm{g} / \mathrm{L}(95 \% \mathrm{CI} 4.2,15.8)$ higher IGF-1. In contrast, we observed no association between cheese or yogurt intake and IGF-1 concentrations.

Conclusions Our findings are in line with most previous investigations and support the hypothesis that dairy and milk intake are associated with higher IGF-1 concentrations.
\end{abstract}

Katharina Nimptsch

Katharina.Nimptsch@mdc-berlin.de

1 Molecular Epidemiology Research Group, Max Delbrück Center for Molecular Medicine (MDC), Robert-Rössle-Str. 10,13125 Berlin, Germany

2 Department of Infectious Disease Epidemiology, Respiratory Infections Unit, Robert Koch-Institute, Berlin, Germany

3 Digital Health and Machine Learning Research Group, Hasso Plattner Institute, Potsdam, Germany

4 Division of Chronic Disease Epidemiology, Epidemiology, Biostatistics and Prevention Institute, University of Zurich, Zurich, Switzerland

5 Center for Endocrinology and Metabolism, Munich, Germany
6 Medicover Neuroendocrinology, Munich, Germany

7 Clinical Neuroendocrinology, Max-Planck-Institute, Munich, Germany

8 Medizinische Klinik und Poliklinik IV, Klinikum der Ludwig-Maximilians-Universität, Munich, Germany

9 Charité Universitätsmedizin, Berlin, Germany

10 Berlin Institute of Health, Berlin, Germany

11 DZHK (German Center for Cardiovascular Research), partner site Berlin, Berlin, Germany

12 Chair of Epidemiology, Ludwig-Maximilians-Universität München, at UNIKA-T Augsburg, Augsburg, Germany

13 Clinical Epidemiology, Helmholtz Zentrum München, Munich, Germany 


\section{Introduction}

Insulin-like growth factor 1 (IGF-1) is a member of the IGF family, an evolutionary conserved group of factors that mediate cell growth, apoptosis and differentiation [1] thereby exerting long-term effects on growth. Most circulating IGF-1 originates from the liver and is bound to IGF-binding proteins (IGFBPs). Only approximately $1 \%$ of IGF-1 is circulating as free fraction (free IGF-1) [2]. IGF-1 does not only activate growth, differentiation and survival in healthy cells, but also in cells with genetic damage $[3,4]$.

Circulating IGF-1 concentrations have been associated with higher cancer risk, particularly prostate [5], colorectal [6] and breast cancer [7]. Dairy intake, in particular milk intake, has been related to higher risk of prostate cancer, and it has been hypothesized that this observation may be mediated by IGF-1 [8].

A number of observational studies [9-22] in adults have described a positive association between milk and dairy products intake and circulating IGF-1 levels, but results have not always been consistent. Almost all of these studies used food frequency questionnaires (FFQs) as dietary assessment, and to our knowledge, only one study [14] used a more detailed instrument such as 24-h dietary recalls. It has been shown that bias in reporting energy and protein intake is greater with FFQ than with 24-h recalls [23].

Thus, the aim of this study was to examine the relationship between dairy intake and circulating IGF-1 concentrations in the Second Bavarian Food Consumption Survey (BVS II), where dietary intake was assessed by three 24-h dietary recalls conducted within 6 weeks before and after blood sampling. The findings of this investigation provide for the first time data on this association in a German population and may contribute to the further clarification of the relationship between dairy intake and IGF- 1 concentrations.

\section{Methods}

\section{Study population}

BVS II is a cross-sectional study designed to provide representative data on the dietary habits of the Bavarian population. Its study design has been described previously [24]. Eligible participants were German-speaking individuals from the Bavarian population, 13-80 years old, who lived in private homes (i.e., non-institutionalized). Between September 2002 and June 2003, 1050 individuals were enrolled in the study by a random route sampling method, with an overall response rate of 70.9\% [25]. The BVS II survey included three phases. The first phase was a personal computer-assisted interview about nutritional and activity habits and the participants' medical history. The second phase consisted of a series of three unannounced 24-h dietary recalls to assess food consumption and physical activity, which was carried out on two weekdays and one weekend day within approximately 14 days by telephone. The dietary assessment was completed by 896 of the initial 1050 participants, corresponding to a response rate of $85.3 \%$ for this second phase. Adult study participants $(\geq 18$ years) who had participated in the interview and in at least one 24-h dietary recall $(n=879)$ were invited to a regional public health office to obtain anthropometric measures and blood samples. The invitation was followed by 568 adult participants, corresponding to a $65 \%$ response rate for this step. The study was conducted according to the guidelines laid down in the Declaration of Helsinki, and all procedures involving human subjects were ethically approved by the Bavarian Ministry of Health and the Bavarian Chamber of Physicians' Ethics Committee (Bayerische Landesärztekammer). All participants participated voluntarily in the study, giving written consent.

\section{Sample collection and laboratory analysis}

Venous blood was collected into EDTA tubes, and refrigerated at $4{ }^{\circ} \mathrm{C}$. The samples were separated into plasma and blood cells using a centrifuge $(1467 \times g$ for $15 \mathrm{~min})$ within $3 \mathrm{~h}$. The separated aliquots were stored at $-80^{\circ} \mathrm{C}$ until analysis. IGF-1 was measured in plasma samples by the Clinical Neuroendocrinology Group of the Max Planck Institute of Psychiatry in Munich with an automated chemiluminescence system (Nichols Institute Diagnostics, San Clemente, CA, USA). The maximal intra- and interassay coefficients of variation were $5 \%$ and $7 \%$, respectively. The measurements were performed according to the manufacturer's instructions and with reagents recommended by the manufacturer.

\section{Dietary intake assessment}

The 24-h dietary recalls were conducted by trained interviewers and recorded with EPIC-SOFT, a software designed specifically for the European Prospective Investigation into Cancer and Nutrition (EPIC) study from the International Agency for Research on Cancer (IARC) in Lyon [26, 27]. During each of the three 24 -h recalls conducted by telephone, participants reported all foods consumed the previous day (covering $24 \mathrm{~h}$ ), which were subsequently specified and quantified using photographs, standard units, household measures or exact amount (in grams or milliliters). Mean 
daily food intake was calculated as average intake from the three recalls, weighed by weekdays and weekend days. All participants who provided at least two 24-h dietary recalls were included in the dietary dataset (mean number of recalls 2.99, standard deviation 0.07). In our analysis, we focused on dairy intake as well as the dairy subgroups milk, cheese and yogurt; the consumed amount of other dairy products (fromage blanc, pudding, etc.) was negligible.

\section{Statistical analysis}

Data on dietary intake from 24-h dietary recalls and IGF-1 concentrations were available for 526 of the 568 BVS II participants with available blood samples $(n=7$ had missing dietary data and $n=35$ missing IGF-1), which was the sample used in all analyses. We present participants' characteristics across quintiles of dairy intake. Multivariable adjusted linear regression models were used to investigate the association between dairy intake (independent variable) and IGF-1 concentrations (dependent variable). The normality and homoscedasticity assumptions underlying the inference on the linear regression coefficients were checked visually using scatterplots and quantile-quantile plots of the residuals. As the residuals showed a slight deviation from the normal distribution, we repeated the regression analysis with log-transformed IGF-1, in which the residuals were normally distributed. Since the estimates of the regression coefficients and all other results were similar in both models, we opted to present the analysis based on the non-transformed IGF-1 levels to facilitate the interpretation of the results. Dairy intake was analyzed categorically, calculating multivariable adjusted mean IGF-1 concentrations and 95\% confidence intervals (CI) by quintiles, as well as continuously (based on approximate portion sizes in accordance with a standard German nutrition guide [28]. Milk, cheese and yogurt intake were only analyzed as continuous variables. The first regression model (model 1) was adjusted for age and sex, and the second model (model 2) additionally included smoking status (never, former, current), body mass index (BMI, kg/ $\mathrm{m}^{2}$ ), physical activity (MET-hours/day), alcohol intake (nondrinker or continuously in g/day), and total energy intake as covariates. Test for trend across quintiles was performed by adding a variable with the quintile medians as continuous variable to the regression model and testing its effect using Wald's test.

We evaluated potential effect modification in the association between dairy intake and IGF-1 by sex, age, BMI and physical activity in an interaction analysis using crossproduct terms between dairy intake and sex, age, BMI and hours of physical activity. To test the assumption of a linear association between dairy intake and IGF-1 concentrations, a linear regression model with addition of a quadratic term to the main effect of dairy intake was fitted.
All statistical analyses were performed with SAS ${ }^{\circledR}$ Enterprise Guide ${ }^{\circledR} 4.3$ (SAS Institute Inc., Cary, North Carolina, USA).

\section{Results}

Participants in the upper quintiles of dairy intake were younger, more often female, had a lower BMI and higher physical activity compared to participants in the lower quintiles (Table 1).

In the main regression analysis, we observed a positive association between dairy intake and IGF-1 in both model 1 ( $p$ trend 0.002) and model 2 ( $p$ trend 0.005, Table 2). Adjusted IGF-1 means increased across quintiles of dairy intake, with similar estimates in the 4th and 5th quintiles in both models (Fig. 1). Each $400 \mathrm{~g}$ increment in daily dairy intake was associated with $16.8 \mu \mathrm{g} / \mathrm{L}$ (95\% CI 6.9, 26.7) higher IGF-1 concentrations in model 2 . Additional adjustment for social stratum and body height yielded similar estimates (data not shown). In further analyses of the subcategories of dairy (Table 3), we observed a positive association between milk and IGF-1 concentrations. Each $200 \mathrm{~g}$ increment in milk per day was associated with $10.0 \mu \mathrm{g} / \mathrm{L}(95 \%$ CI 4.2, 15.8) higher IGF-1 levels in model 2. In contrast, we observed no association between cheese or yogurt intake and IGF-1 concentrations. We did not observe any statistically significant interactions by sex, age groups, BMI categories or physical activity (data not shown). Finally, the regression with quadratic terms for dairy intake did not indicate nonlinear associations (data not shown).

\section{Discussion}

The present study examined the relationship between dairy consumption and circulating IGF-1 concentrations using the data from the BVS II, thus providing for the first time information on this association for a German population. A positive association between dairy and milk intake and IGF-1 levels was observed that persisted after multivariable adjustments for age, sex, BMI, smoking status, physical activity, alcohol and energy intake. However, no association between yogurt or cheese intake and IGF-1 concentrations was observed.

The biological mechanisms that may explain the observed positive association between dairy intake and IGF-1 were not elucidated. Epidemiological studies suggested that dairy protein may play a role $[11,19]$, which is supported by animal studies showing that all essential amino acids upregulate hepatic IGF-1 gene expression [29], and availability of protein and amino acids influences circulating IGF-1 concentrations [30, 31]. A mediating role of dairy calcium and 
Table 1 Participants' characteristics by quintiles of dairy intake, Bavarian Food Consumption Survey II

\begin{tabular}{|c|c|c|c|c|c|c|}
\hline & Total & Quintile 1 & Quintile 2 & Quintile 3 & Quintile 4 & Quintile 5 \\
\hline$N$ & 526 & 105 & 105 & 106 & 105 & 105 \\
\hline $\begin{array}{l}\text { Age (years), mean } \\
\text { (SD) }\end{array}$ & $48.6(15.2)$ & $51.8(15.4)$ & $49.9(14.5)$ & $51.2(14.9)$ & $45.7(14.5)$ & $44.3(15.3)$ \\
\hline \multicolumn{7}{|l|}{$\operatorname{Sex}-n(\%)$} \\
\hline Men & $220(42)$ & $56(53.3)$ & $44(41.9)$ & $44(41.5)$ & $38(36.2)$ & $38(36.2)$ \\
\hline Women & $306(58)$ & $49(46.7)$ & $61(58.1)$ & $62(58.5)$ & $67(63.8)$ & $67(63.8)$ \\
\hline $\begin{array}{c}\mathrm{BMI}\left(\mathrm{kg} / \mathrm{m}^{2}\right) \\
\text { mean }(\mathrm{SD})\end{array}$ & $26.6(4.9)$ & $27.5(5.0)$ & $26.4(4.3)$ & $27.1(5.2)$ & $26.4(4.6)$ & $25.4(4.9)$ \\
\hline $\begin{array}{l}\text { Height }(\mathrm{cm}) \text {, mean } \\
\text { (SD) }\end{array}$ & $168(8.6)$ & $167(8.6)$ & $168(7.5)$ & $168(9.6)$ & $169(8.3)$ & $169(9.1)$ \\
\hline \multicolumn{7}{|c|}{ Social stratum ${ }^{\mathrm{a}}-n(\%)$} \\
\hline Lower layer & $71(14)$ & $15(14.3)$ & $16(15.2)$ & $12(11.3)$ & $16(15.2)$ & $12(11.4)$ \\
\hline $\begin{array}{l}\text { Lower middle } \\
\text { layer }\end{array}$ & $127(24)$ & $37(35.2)$ & $27(25.7)$ & $21(19.8)$ & $21(20.0)$ & $21(20.0)$ \\
\hline Middle layer & $167(32)$ & $35(33.3)$ & $26(24.8)$ & $35(33.0)$ & $35(33.3)$ & $36(34.3)$ \\
\hline $\begin{array}{l}\text { Upper middle } \\
\text { layer }\end{array}$ & $110(21)$ & $17(16.2)$ & $28(26.7)$ & $24(22.6)$ & $19(18.1)$ & $22(21.0)$ \\
\hline Upper layer & $51(10)$ & $1(1.0)$ & $8(7.6)$ & $14(13.2)$ & $14(13.3)$ & $14(13.3)$ \\
\hline \multicolumn{7}{|c|}{ Smoking status $-n(\%)$} \\
\hline Never smoked & $274(52)$ & $55(52.4)$ & $52(49.5)$ & $59(55.7)$ & $50(47.6)$ & $58(55.2)$ \\
\hline Former smoker & $124(24)$ & $19(18.1)$ & $19(18.1)$ & $28(26.4)$ & $30(28.6)$ & $28(26.7)$ \\
\hline Current smoker & $128(24)$ & $31(29.5)$ & 34 (32.4) & $19(17.9)$ & $25(23.8)$ & $19(18.1)$ \\
\hline $\begin{array}{l}\text { Physical activ- } \\
\text { ity, MET-h/day, } \\
\text { median }\left(Q_{0.25},\right. \\
\left.Q_{0.75}\right)\end{array}$ & $10.2(4.3,17.4)$ & $10.1(8.9)$ & $11.6(8.7)$ & $10.2(9.0)$ & $13.7(12.5)$ & $13.0(11.0)$ \\
\hline \multicolumn{7}{|c|}{ Dietary intake, median $\left(Q_{0.25}, Q_{0.75}\right)$} \\
\hline $\begin{array}{l}\text { Energy (kcal/ } \\
\text { day) }\end{array}$ & $1926(1531,2333)$ & $1783(1360,2191)$ & $1892(1430,2331)$ & $1926(1571,2304)$ & $1954(1586,2406)$ & $2073(1714,2509)$ \\
\hline $\begin{array}{l}\text { Alcohol (ethanol, } \\
\text { g/day) }\end{array}$ & $7.1(0.2,19.7)$ & $9.0(0.1,25.5)$ & $6.1(0.3,19.6)$ & $8.0(0.4,20.2)$ & $7.6(0.2,19.2)$ & $5.7(0.2,15.3)$ \\
\hline $\begin{array}{l}\text { Total dairy }(\mathrm{g} / \\
\text { day) }\end{array}$ & $\begin{array}{l}137.9(65.6 \\
261.1)\end{array}$ & $28.1(11.4,38.9)$ & $76.7(65.6,92.0)$ & $\begin{array}{l}137.9(120.8, \\
160.0)\end{array}$ & $\begin{array}{l}227.5(198.5 \\
261.1)\end{array}$ & $374.2(347.9,462.1)$ \\
\hline Milk (g/day) & $44.3(8.7,141.2)$ & $7.7(0.0,16.6)$ & $18.7(0.0,35.7)$ & $58.8(8.9,89.3)$ & $120.0(57.1,191.7)$ & $258.7(178.6,332.2)$ \\
\hline Cheese (g/day) & $22.7(8.6,39.0)$ & $10.7(0.0,19.0)$ & $25.1(10.7,40.2)$ & $26.9(7.9,42.5)$ & $29.1(16.9,46.5)$ & $30.0(13.9,52.3)$ \\
\hline Yogurt (g/day) & $0.0(0,53.6)$ & $0.00(0,0)$ & $0.00(0,9.9)$ & $0.00(0,53.6)$ & $35.21(0,96.4)$ & $67.86(0,164.6)$ \\
\hline $\begin{array}{l}\text { Serum IGF-I lev- } \\
\text { els }(\mu \mathrm{g} / \mathrm{L}) \text {, mean } \\
(\mathrm{SD})\end{array}$ & $133.6(51.6)$ & $113.7(46.3)$ & $128.4(47.6)$ & $133.4(56.3)$ & $145.1(55.8)$ & $147.5(44.5)$ \\
\hline
\end{tabular}

$Q_{0.25}$ and $Q_{0.75}$ stand for the 25 th and 75 th percentiles

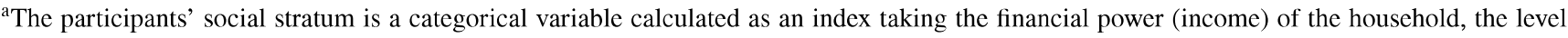
of education, and the professional position. The subjects were divided into five social strata: lower layer (1), lower middle layer (2), middle layer (3), upper middle layer (4), and upper layer (5). This index was already available in the database

phosphorus in the positive association between dairy and IGF-1 has also been suggested [11-13, 15, 19, 32], but this hypothesis is not supported by our findings, since we did not observe an association with cheese intake, which is a good source of both calcium and phosphorus. Another hypothesis suggests that the milk-borne IGF-1, which appears to be very similar to the human IGF-1, could be absorbed, exerting metabolic effects on liver and other peripheral tissues.
A study in neonatal rats showed that radioactively labeled milk-borne IGF-1 appeared in low concentrations in the portal circulation [33]. However, these results cannot be easily transferred to human adults.

Our results are consistent with previous studies. We compared our results with those of 14 previous cross-sectional studies that also investigated intake of milk or dairy intake in relation to circulating IGF-1 concentrations [9-22]. Of 
Table 2 Multivariable adjusted mean IGF-1 concentrations $(\mu \mathrm{g} / \mathrm{L})$ by quintiles of dairy intake in the Bavarian Food Consumption Survey II

\begin{tabular}{|c|c|c|c|c|c|c|c|}
\hline & & Quintile 1 & Quintile 2 & Quintile 3 & Quin & & Quintile 5 \\
\hline \multicolumn{2}{|c|}{ Quintile range (g/day) } & $0-48.8$ & $49.0-105.9$ & \multicolumn{2}{|c|}{$106.4-174.4$} & 300.9 & $302.6-1547.5$ \\
\hline & $\begin{array}{l}\text { Quintile } 1 \\
\text { Mean (95\% CI) }\end{array}$ & $\begin{array}{l}\text { Quintile } 2 \\
\text { Mean (95\% CI) }\end{array}$ & $\begin{array}{l}\text { Quintile } 3 \\
\text { Mean (95\% CI) }\end{array}$ & $\begin{array}{l}\text { Quintile } 4 \\
\text { Mean (95\% CI) }\end{array}$ & $\begin{array}{l}\text { Quintile } 5 \\
\text { Mean (95\% CI) }\end{array}$ & $p$ trend & $\begin{array}{l}\text { Continuous estimate } \\
(95 \% \mathrm{CI}) \text { per } 400 \mathrm{~g} \\
\text { dairy/day }\end{array}$ \\
\hline Model $1^{\mathrm{a}}$ & $119.3(111.1-12$ & $130.6(122.4,13$ & ) $137.6(129.4,14$ & ) $139.7(131.4,14$ & ) $139.6(131.3,14$ & 9) 0.002 & $18.1(8.6,27.6)$ \\
\hline Model $2^{\mathrm{b}}$ & $121.0(111.9,13$ & ) $132.4(123.2,14$ & 6) $138.7(129.6,147$ & ) $141.8(132.9,15$ & ) $140.0(130.5,14$ & 5) 0.005 & $16.8(6.9,26.7)$ \\
\hline
\end{tabular}

${ }^{\mathrm{a} A g e}$ and sex adjusted

${ }^{\mathrm{b}}$ Adjusted for age (years), sex, smoking status (never, former, current), BMI $\left(\mathrm{kg} / \mathrm{m}^{2}\right.$ ), physical activity (MET-h/day), alcohol intake (nondrinker or $\mathrm{g} / \mathrm{day})$, total energy intake (kcal/day)

Fig. 1 Multivariable adjusted mean IGF-1 concentrations with $95 \%$ confidence intervals by quintiles of dairy intake in the Bavarian Food Consumption Survey II. Bars indicate $95 \%$ confidence intervals. Model 1: age and sex adjusted. Model 2: adjusted for age, sex, smoking status, BMI, physical activity, alcohol intake (nondrinker or $\mathrm{g} /$ day), total energy intake (gcal/ day)

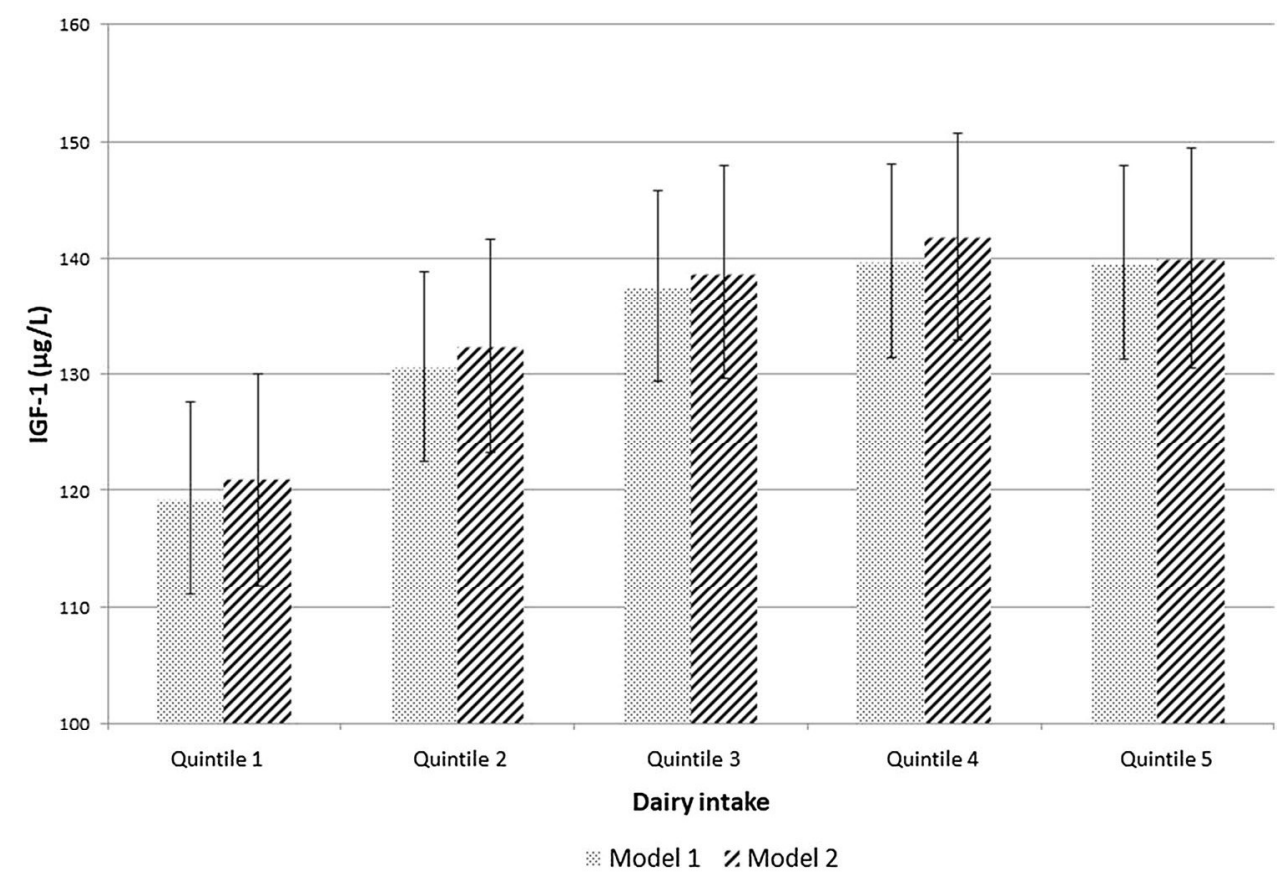

Table 3 Association between dietary intake of milk, cheese and yogurt and IGF-1 in the Bavarian Food Consumption Survey II

\begin{tabular}{lll}
\hline & Beta $(95 \%$ CI $)$ & $p$ Value \\
\hline Milk consumption (per 200 g/day) & & \\
Model 1 & $11.0(5.3,16.6)$ & 0.0002 \\
Model 2 & $10.0(4.2,15.8)$ & 0.0007 \\
Cheese consumption (per 30 g/day) & & \\
Model 1 & $0.7(-3.3,4.7)$ & 0.74 \\
Model 2 & $0.4(-3.7,4.5)$ & 0.84 \\
Yogurt consumption (per 150 g/day) & & \\
Model 1 $^{\mathrm{b}}$ & $3.9(-4.8,12.6)$ & 0.38 \\
Model 2 & $3.4(-5.3,12.2)$ & 0.44 \\
\hline
\end{tabular}

${ }^{\mathrm{a}}$ Age and sex adjusted

${ }^{\mathrm{b}}$ Adjusted for age (years), sex, smoking status (never, former, current), BMI $\left(\mathrm{kg} / \mathrm{m}^{2}\right)$, physical activity (MET-h/day), alcohol intake (nondrinker or $\mathrm{g} / \mathrm{day}$ ), total energy intake (kcal/day) them, seven studies $[9,11-13,15,17,19,21]$ found a statistically significant positive association between milk or dairy intake and IGF-1 levels, while one study found only significant associations for black, but not for white men [16]. Five studies found no significant association between dairy intake and IGF-1 concentrations $[10,12,14,18,20]$. In the most recent publication, a study from the Women's Health Initiative [22], a positive association between milk intake and free but not total IGF-1 was observed. In the only study in adults that used 24-h dietary recalls instead of FFQ [14], milk intake was not significantly associated with IGF-1 concentrations. In contrast to our study, where the three dietary recalls were conducted relatively close in time to the blood collection (on random days within 6 weeks, before and after blood collection), in the study by Larsson et al. [14], 24-h dietary recalls by telephone were performed over 1 year to estimate long-term dietary intake. Most previous studies 
investigated only total dairy and milk, but not other dairy products. Consistent with our findings, one previous study observed a significant positive association of milk but not yogurt or cheese intake with IGF-1 [13], while in another publication, both milk and yogurt showed significant positive associations, but no association was observed for cheese intake [19]. The different associations of various dairy products with IGF-1 may be related to different consumption frequencies (milk is more often consumed than yogurt or cheese), differences in the accuracy of recall or may have a yet unknown biological explanation. Further support for a positive association between milk and IGF-1 comes from a randomized controlled trial conducted in 204 men and women aged 55-85 years, which showed that a 12-week milk intervention versus control increased serum IGF-1 concentrations [34]. Similar results were found in intervention studies in children [35-37]. In a recent meta-analysis of 28 studies including randomized controlled trials, nonrandomized intervention studies and cross-sectional investigations, moderate evidence for a positive association of milk and dairy intake with circulating IGF-1 was reported [8]. In the same publication, in a meta-analysis on IGF-1 and prostate cancer, moderate evidence for circulating IGF-1 being associated with higher prostate cancer risk was observed and authors concluded that the available evidence supports a mediating role of IGF-1 in the positive association between milk consumption and prostate cancer risk.

Our study has some limitations that should be considered. In BVS II, only IGF-1, but none of its binding proteins, such as the main binding protein IGFBP-3 was measured. Thus, we were not able to account for IGFBP-3 in our analyses. For example, we could not investigate the IGF-1/IGFBP-3 ratio, but our analyses of dairy and IGF-1 are comparable to the IGF-1 analyses of the previous cross-sectional studies, which did not include IGFBP-3 as adjustment variable [9-17, 19-22] with only one exception [18]. We also did not specifically measure free IGF-1, which has been employed in more recent investigations [22]. Another limitation of our study is that dietary intake of protein or calcium was not available by source, so we could not investigate potentially mediating effects of dairy protein or calcium. Finally, dietary intake derived from the three 24-h dietary recalls may be subject to measurement error. On the other hand, it has been shown that multiple 24-h dietary recalls result in less reporting bias than FFQs [23, 38, 39], particularly for frequently consumed foods such as milk and dairy, which renders the use of three 24-h dietary recalls as dietary assessment a strength of our study. Furthermore, compared to most previous publications, which used FFQs usually covering the habitual diet in the previous year as dietary assessment, in the present study dietary intake was assessed closely to the blood collection date, i.e., within up to 6 weeks before and after blood collection, which enables us to examine mid-term effects. The further strengths of our study were that we had a broad range of dairy intakes, ranging from very low to very high intake, data on men and women as well as a broad age range (19-81 years), whereas many of the previous studies investigating dairy intake in relation to IGF-1 concentrations only included one sex [11, 12, 14-16, 18-22] or had a narrow age range $[9,10,12,14,21,22]$.

\section{Conclusion}

In this investigation using multiple 24-h dietary recalls as the dietary assessment method which were collected closely to the blood collection date, we observed a statistically significant positive association between dairy and milk intake and IGF-1 concentrations, whereas no association was observed for cheese or yogurt. Our findings are in line with most cross-sectional studies using FFQs as the dietary assessment. Together with the available evidence from randomized controlled trials, these findings support the hypothesis that circulating IGF-1 may be modified by alterations in dairy intake, which may be utilized in dietary recommendations for cancer prevention.

Acknowledgements The authors acknowledge the cooperation of all study participants. We thank Georg Karg, Kurt Gedrich and Stefanie Himmerich for their major contribution in the setup and conduct of the Second Bavarian Food Consumption Survey. This work was supported by funds of the Bavarian Ministry of Environment, Health and Consumer Protection and the Kurt-Eberhard-Bode-Stiftung. The funder had no role in the design, analysis or writing of this article

\section{Compliance with ethical standards}

Conflict of interest The authors declare that they have no conflict of interest.

\section{References}

1. van Heemst D (2010) Insulin, IGF-1 and longevity. Aging Dis 1(2):147-157

2. Juul A, Bang P, Hertel NT, Main K, Dalgaard P, Jorgensen K, Muller J, Hall K, Skakkebaek NE (1994) Serum insulin-like growth factor-I in 1030 healthy children, adolescents, and adults: relation to age, sex, stage of puberty, testicular size, and body mass index. J Clin Endocrinol Metab 78(3):744-752

3. Fürstenberger G, Senn H-J (2002) Insulin-like growth factors and cancer. Lancet Oncol 3(5):298-302. https://doi.org/10.1016/ S1470-2045(02)00731-3

4. Macaulay VM (1992) Insulin-like growth factors and cancer. $\mathrm{Br}$ J Cancer 65(3):311-320

5. Travis RC, Appleby PN, Martin RM, Holly JMP, Albanes D, Black A, Bueno-de-Mesquita HBA, Chan JM, Chen C, Chirlaque MD, Cook MB, Deschasaux M, Donovan JL, Ferrucci L, Galan P, Giles GG, Giovannucci EL, Gunter MJ, Habel LA, Hamdy FC, Helzlsouer KJ, Hercberg S, Hoover RN, Janssen J, Kaaks R, Kubo T, Le Marchand L, Metter EJ, Mikami K, Morris JK, Neal 
DE, Neuhouser ML, Ozasa K, Palli D, Platz EA, Pollak M, Price AJ, Roobol MJ, Schaefer C, Schenk JM, Severi G, Stampfer MJ, Stattin P, Tamakoshi A, Tangen CM, Touvier M, Wald NJ, Weiss NS, Ziegler RG, Key TJ, Allen NE (2016) A meta-analysis of individual participant data reveals an association between circulating levels of IGF-I and prostate cancer risk. Can Res 76(8):22882300. https://doi.org/10.1158/0008-5472.CAN-15-1551

6. Rinaldi S, Cleveland R, Norat T, Biessy C, Rohrmann S, Linseisen J, Boeing H, Pischon T, Panico S, Agnoli C, Palli D, Tumino R, Vineis P, Peeters PH, van Gils CH, Bueno-de-Mesquita BH, Vrieling A, Allen NE, Roddam A, Bingham S, Khaw KT, Manjer J, Borgquist S, Dumeaux V, Torhild Gram I, Lund E, Trichopoulou A, Makrygiannis G, Benetou V, Molina E, Donate Suarez I, Barricarte Gurrea A, Gonzalez CA, Tormo MJ, Altzibar JM, Olsen A, Tjonneland A, Gronbaek H, Overvad K, Clavel-Chapelon F, Boutron-Ruault MC, Morois S, Slimani N, Boffetta P, Jenab M, Riboli E, Kaaks R (2010) Serum levels of IGF-I, IGFBP-3 and colorectal cancer risk: results from the EPIC cohort, plus a metaanalysis of prospective studies. Int J Cancer 126(7):1702-1715

7. Hormones TE, Breast Cancer Collaborative Group (2010) Insulinlike growth factor 1 (IGF1), IGF binding protein 3 (IGFBP3), and breast cancer risk: pooled individual data analysis of 17 prospective studies. Lancet Oncol 11(6):530-542

8. Harrison S, Lennon R, Holly J, Higgins JPT, Gardner M, Perks C, Gaunt T, Tan V, Borwick C, Emmet P, Jeffreys M, Northstone K, Rinaldi S, Thomas S, Turner SD, Pease A, Vilenchick V, Martin RM, Lewis SJ (2017) Does milk intake promote prostate cancer initiation or progression via effects on insulin-like growth factors (IGFs)? A systematic review and meta-analysis. Cancer Causes Control 28(6):497-528. https://doi.org/10.1007/s1055 2-017-0883-1

9. Crowe FL, Key TJ, Allen NE, Appleby PN, Roddam A, Overvad K, Gronbaek H, Tjonneland A, Halkjaer J, Dossus L, Boeing H, Kroger J, Trichopoulou A, Dilis V, Trichopoulos D, BoutronRuault MC, De Lauzon B, Clavel-Chapelon F, Palli D, Berrino F, Panico S, Tumino R, Sacerdote C, Bueno-de-Mesquita HB, Vrieling A, van Gils CH, Peeters PH, Gram IT, Skeie G, Lund E, Rodriguez L, Jakszyn P, Molina-Montes E, Tormo MJ, Barricarte A, Larranaga N, Khaw KT, Bingham S, Rinaldi S, Slimani N, Norat T, Gallo V, Riboli E, Kaaks R (2009) The association between diet and serum concentrations of IGF-I, IGFBP-1, IGFBP-2, and IGFBP-3 in the European Prospective Investigation into Cancer and Nutrition. Cancer Epidemiol Biomark Prev 18(5):1333-1340. https://doi.org/10.1158/1055-9965.EPI-08-0781

10. DeLellis K, Rinaldi S, Kaaks RJ, Kolonel LN, Henderson B, Le Marchand L (2004) Dietary and lifestyle correlates of plasma insulin-like growth factor-I (IGF-I) and IGF binding protein-3 (IGFBP-3): the multiethnic cohort. Cancer Epidemiol Biomark Prev 13(9):1444-1451

11. Giovannucci E, Pollak M, Liu Y, Platz EA, Majeed N, Rimm EB, Willett WC (2003) Nutritional predictors of insulin-like growth factor I and their relationships to cancer in men. Cancer Epidemiol Biomarkers Prev 12(2):84-89

12. Gunnell D, Oliver SE, Peters TJ, Donovan JL, Persad R, Maynard M, Gillatt D, Pearce A, Hamdy FC, Neal DE, Holly JMP (2003) Are diet-prostate cancer associations mediated by the IGF axis? A cross-sectional analysis of diet, IGF-I and IGFBP-3 in healthy middle-aged men. Br J Cancer 88(11):1682-1686. https://doi. org/10.1038/sj.bjc. 6600946

13. Holmes MD, Pollak MN, Willett WC, Hankinson SE (2002) Dietary correlates of plasma insulin-like growth factor I and insulinlike growth factor binding protein 3 concentrations. Cancer Epidemiol Biomark Prev 11(9):852-861

14. Larsson SC, Wolk K, Brismar K, Wolk A (2005) Association of diet with serum insulin-like growth factor I in middle-aged and elderly men. Am J Clin Nutr 81(5):1163-1167. https://doi. org/10.1093/ajcn/81.5.1163

15. Ma J, Giovannucci E, Pollak M, Chan JM, Gaziano JM, Willett W, Stampfer MJ (2001) Milk intake, circulating levels of insulinlike growth factor-I, and risk of colorectal cancer in men. J Natl Cancer Inst 93(17): 1330-1336

16. McGreevy KM, Hoel BD, Lipsitz SR, Hoel DG (2007) Impact of nutrients on insulin-like growth factor-I, insulin-like growth factor binding protein-3 and their ratio in African American and white males. Public Health Nutr 10(1):97-105. https://doi.org/10.1017/ S1368980007217999

17. Morimoto LM, Newcomb PA, White E, Bigler J, Potter JD (2005) Variation in plasma insulin-like growth factor-1 and insulin-like growth factor binding protein-3: personal and lifestyle factors (United States). Cancer Causes Control CCC 16(8):917-927. https ://doi.org/10.1007/s10552-005-2702-3

18. Mucci LA, Tamimi R, Lagiou P, Trichopoulou A, Benetou V, Spanos E, Trichopoulos D (2001) Are dietary influences on the risk of prostate cancer mediated through the insulin-like growth factor system? BJU Int 87(9):814-820

19. Norat T, Dossus L, Rinaldi S, Overvad K, Gronbaek H, Tjonneland A, Olsen A, Clavel-Chapelon F, Boutron-Ruault MC, Boeing H, Lahmann PH, Linseisen J, Nagel G, Trichopoulou A, Trichopoulos D, Kalapothaki V, Sieri S, Palli D, Panico S, Tumino R, Sacerdote C, Bueno-de-Mesquita HB, Peeters PH, van Gils CH, Agudo A, Amiano P, Ardanoz E, Martinez C, Quiros R, Tormo MJ, Bingham S, Key TJ, Allen NE, Ferrari P, Slimani N, Riboli E, Kaaks R (2007) Diet, serum insulin-like growth factor-I and IGF-binding protein-3 in European women. Eur J Clin Nutr 61(1):91-98. https://doi.org/10.1038/sj.ejen.1602494

20. Signorello LB, Kuper H, Lagiou P, Wuu J, Mucci LA, Trichopoulos D, Adami HO (2000) Lifestyle factors and insulin-like growth factor 1 levels among elderly men. Eur J Cancer Prev 9(3):173-178

21. Young NJ, Metcalfe C, Gunnell D, Rowlands MA, Lane JA, Gilbert R, Avery KN, Davis M, Neal DE, Hamdy FC, Donovan J, Martin RM, Holly JM (2012) A cross-sectional analysis of the association between diet and insulin-like growth factor (IGF)-I, IGF-II, IGF-binding protein (IGFBP)-2, and IGFBP-3 in men in the United Kingdom. Cancer Causes Control CCC 23(6):907-917. https://doi.org/10.1007/s10552-012-9961-6

22. Beasley JM, Gunter MJ, LaCroix AZ, Prentice RL, Neuhouser ML, Tinker LF, Vitolins MZ, Strickler HD (2013) Associations of serum insulin-like growth factor-I and insulin-like growth factorbinding protein 3 levels with biomarker-calibrated protein, dairy product and milk intake in the Women's Health Initiative. Br J Nutr 111(05):847-853. https://doi.org/10.1017/s00071145130031 $9 \mathrm{x}$

23. Freedman LS, Commins JM, Moler JE, Arab L, Baer DJ, Kipnis V, Midthune D, Moshfegh AJ, Neuhouser ML, Prentice RL, Schatzkin A, Spiegelman D, Subar AF, Tinker LF, Willett W (2014) Pooled results from 5 validation studies of dietary selfreport instruments using recovery biomarkers for energy and protein intake. Am J Epidemiol 180(2):172-188. https://doi. org/10.1093/aje/kwu116

24. Schwedhelm C, Pischon T, Rohrmann S, Himmerich H, Linseisen J, Nimptsch K (2017) Plasma inflammation markers of the tumor necrosis factor pathway but not $\mathrm{C}$-reactive protein are associated with processed meat and unprocessed red meat consumption in bavarian adults. J Nutr 147(1):78-85. https://doi.org/10.3945/ jn. 116.237180

25. Himmerich S, Gedrich K, Karg G (2004) Bayerische Verzehrsstudic (BVS) II Abschlussbericht. Bayerisches Staatsministerium für Umwelt, Gesundheit und Verbraucherschutz, München-Weihenstephan 
26. Slimani N, Deharveng G, Charrondiere RU, van Kappel AL, Ocke MC, Welch A, Lagiou A, van Liere M, Agudo A, Pala V, Brandstetter B, Andren C, Stripp C, van Staveren WA, Riboli E (1999) Structure of the standardized computerized 24-h diet recall interview used as reference method in the 22 centers participating in the EPIC project. European prospective investigation into cancer and nutrition. Comput Methods Progr Biomed 58(3):251-266

27. Slimani N, Ferrari P, Ocke M, Welch A, Boeing H, Liere M, Pala V, Amiano P, Lagiou A, Mattisson I, Stripp C, Engeset D, Charrondiere R, Buzzard M, Staveren W, Riboli E (2000) Standardization of the 24-hour diet recall calibration method used in the european prospective investigation into cancer and nutrition (EPIC): general concepts and preliminary results. EurJClinNutr 54(12):900-917

28. Umschau (2003) Kalorien mundgerecht. Nestlé Deutschland AG, Frankfurt/Main

29. Thissen JP, Pucilowska JB, Underwood LE (1994) Differential regulation of insulin-like growth factor I (IGF-I) and IGF binding protein-1 messenger ribonucleic acids by amino acid availability and growth hormone in rat hepatocyte primary culture. Endocrinology 134(3):1570-1576. https://doi.org/10.1210/ endo.134.3.7509741

30. Takahashi S, Kajikawa M, Umezawa T, Takahashi S, Kato H, Miura Y, Nam TJ, Noguchi T, Naito H (1990) Effect of dietary proteins on the plasma immunoreactive insulin-like growth factor-1/somatomedin $\mathrm{C}$ concentration in the rat. $\mathrm{Br} \mathrm{J}$ Nutr 63(3):521-534

31. Takenaka A, Oki N, Takahashi SI, Noguchi T (2000) Dietary restriction of single essential amino acids reduces plasma insulin-like growth factor-I (IGF-I) but does not affect plasma IGFbinding protein-1 in rats. J Nutr 130(12):2910-2914. https://doi. org/10.1093/jn/130.12.2910

32. Probst-Hensch NM, Wang H, Goh VH, Seow A, Lee HP, Yu MC (2003) Determinants of circulating insulin-like growth factor I and insulin-like growth factor binding protein 3 concentrations in a cohort of Singapore men and women. Cancer Epidemiol Biomark Prev 12(8):739-746

33. Philipps AF, Dvorak B, Kling PJ, Grille JG, Koldovsky O (2000) Absorption of milk-borne insulin-like growth factor-I into portal blood of suckling rats. J Pediatr Gastroenterol Nutr 31(2):128-135

34. Heaney RP, McCarron DA, Dawson-Hughes B, Oparil S, Berga SL, Stern JS, Barr SI, Rosen CJ (1999) Dietary changes favorably affect bone remodeling in older adults. J Am Diet Assoc 99(10):1228-1233. https://doi.org/10.1016/S0002-8223(99)00302 $-8$

35. Budek AZ, Hoppe C, Michaelsen KF, Bugel S, Molgaard C (2007) Associations of total, dairy, and meat protein with markers for bone turnover in healthy, prepubertal boys. J Nutr 137(4):930-934

36. Rich-Edwards JW, Ganmaa D, Pollak MN, Nakamoto EK, Kleinman K, Tserendolgor U, Willett WC, Frazier AL (2007) Milk consumption and the prepubertal somatotropic axis. Nutr J 6:28. https://doi.org/10.1186/1475-2891-6-28

37. Hoppe C, Molgaard C, Juul A, Michaelsen KF (2004) High intakes of skimmed milk, but not meat, increase serum IGF-I and IGFBP-3 in eight-year-old boys. Eur J Clin Nutr 58(9):12111216. https://doi.org/10.1038/sj.ejcn.1601948

38. Kipnis V, Midthune D, Buckman DW, Dodd KW, Guenther PM, Krebs-Smith SM, Subar AF, Tooze JA, Carroll RJ, Freedman LS (2009) Modeling data with excess zeros and measurement error: application to evaluating relationships between episodically consumed foods and health outcomes. Biometrics 65(4):1003-1010. https://doi.org/10.1111/j.1541-0420.2009.01223.x

39. Prentice RL, Mossavar-Rahmani Y, Huang Y, Van Horn L, Beresford SA, Caan B, Tinker L, Schoeller D, Bingham S, Eaton CB, Thomson C, Johnson KC, Ockene J, Sarto G, Heiss G, Neuhouser ML (2011) Evaluation and comparison of food records, recalls, and frequencies for energy and protein assessment by using recovery biomarkers. Am J Epidemiol 174(5):591-603. https://doi. org/10.1093/aje/kwr140 